\title{
Obesity and its Implications on Stress Urinary Incontinence
}

\author{
MIHAI CRISTIAN DUMITRASCU1,2, ANA MARIA ALEXANDRA STANESCU ${ }^{1}$, CRISTIAN BEJ AN ${ }^{1}$, FLORICA SANDRU ${ }^{1,{ }^{3}}$, \\ DANIELA OANA TOADER ${ }^{1,4}$, DANIEL GEORGE RADAVOI ${ }^{1,5 *}$, ADRIAN COTIRLET ${ }^{6}$, CLAUDIA TEODORA JUDEA PUSTA $^{7}$, \\ CAMELIA CRISTINA DIACONU1,8 \\ IUniversity of Medicine and Pharmacy Carol Davila, 8 Eroii Sanitari Str, Bucharest, 050474, Bucharest, Romania \\ 2Emergency University Hospital Bucharest, 169 Splaiul Independentei, 050098, Bucharest, Romania \\ ${ }^{3}$ Elias University Emergency Hospital, 17 Marasti Blvd., 011461, Bucharest, Romania \\ 4Polizu Clinic, Institute for the Protection of Mother and Child Alessandrescu-Rusescu, 38-52 Gheorghe Polizu Str., Bucharest, \\ Romania \\ ${ }^{5}$ Clinical Hospital Prof. Dr. Th. Burghele, 20 Panduri Road, 050652, Bucharest, Romania \\ Vasile Alecsandri University, Bacau, Municipal Emergency Hospital Moinesti, 1 Zorilor Str, Moinesti, Romania \\ 7University of Oradea, Faculty of Medicine and Pharmacy, Department of Morphological Disciplines, 10, 1 Decembrie Sq., 410073, \\ Oradea, Romania \\ ${ }^{8}$ Clinical Emergency Hospital of Bucharest, 8 Calea Floreasca, 014461, Bucharest, Romania
}

Obesity has reached alarming levels worldwide. Urinary incontinence disorders are associated with a profound negative effecton the quality of life. Obesity in women is associated with stress urinary incontinence. This review aims to highlight the mechanisms, the implications, as well as the best therapeutic approach for stress urinary incontinence in obese women, all following the rigorous documentation of the current research.

Keywords: obesity, stress urinary incontinence, implications

The Centers for Disease Control and Prevention defines overweight and obesity as a body mass index (BMI) of $25.0-30.0 \mathrm{~kg} / \mathrm{m}^{2}$, respectively> $30 \mathrm{~kg} / \mathrm{m}^{2}$ [1]. The prevalence of obesity is alarming globally. In the USA, 38.3\% of women are obese and the prevalence increases with age [2]. With its high prevalence, obesity has been associated with other chronic conditions, such as diabetes, high blood pressure, hyperlipidemia and cardiovascular disease [3].

Also, central obesity can be considered an early step in the development of metabolic syndrome [4]. Given the trend of weight gain in recent decades, central obesity can be considered an epidemic disorder worldwide, with a remarkable socioeconomic impact, mainly due to its association with increased morbidity and mortality $[5,6]$.

Urinary incontinence disorders are associated with a profound negative effect on the quality of life. The relationship between obesity and urinary incontinence has been well documented in cohort studies, obesity has been associated with more frequent episodes of urinary incontinence and a higher prevalence of stress urinary incontinence. Increased body mass index by 5 units is associated with an increase of $20-70 \%$ of the risk of urinary incontinence [7].

Giovannucci et al described, over 20 years ago, for the first time, that patients with a waist circumference e"109 $\mathrm{cm}$ had a higher risk of prostatectomy than those with a waist circumference $<89 \mathrm{~cm}$, suggesting that central obesity may play a role in worsening urinary symptoms [8].

Vignozzi et al demonstrated that the presence of the metabolic syndrome influences the lower symptoms of the urinary tract/ benign prostatic hyperplasia, having a direct pro-inflammatory effect within the prostate; the changes that occur due to the metabolic syndrome are not only in the prostate, but also in the bladder [9]. The generation of inflammatory cytokines from visceral adipose tissue is likely to be an important determinant for a chronic pro-inflammatory state, which characterizes the metabolic syndrome.

Worldwide, obesity has been linked to the development of prostate cancer, with urinary incontinence being one of the most important complications, so some surgeons try to use body mass index as a prognostic factor and indicate in therapeutic recommendations [10-12].

Urinary stress incontinence - urinary leakage associated with physical activity that increases intra-abdominal pressure, for example, laughter, coughing, sneezing and exercise - affects $20 \%$ to $40 \%$ of women [13]. In young women, the onset is usually associated with sports or pregnancy; urinary stress incontinence during pregnancy determines a susceptibility to subsequent surgery as the woman ages [14].

\section{Stress urinary incontinence}

Stress urinary incontinence (SUI) is associated with impaired functioning of the bladder sphincter and/ or pelvic floor muscles, thus the pressure exerted on the abdomen leads to an accidental opening of the urethra and, consequently, urine leakage [15]. Several mechanisms may underlie SUI, from genetic predisposition, gynecological disorders, hormonal changes, physiological changes associated with menopause, constipation, chronic smoking, cough, asthma, pregnancy, to extreme physical activity [15-17].

Pregnancy is a special situation that can compromise the pelvic floor, leading to the appearance of SUI during pregnancy, after birth, or even later in life [14]. Wesnes suggested that multiple births increase the risk for SUI twice, and large body fat deposits and not just baby weight correlate with the onset of urinary leakage [18]. The initial weight before pregnancy is important, the higher the body weight before pregnancy, the more likely the SUI to appear.

Stress urinary incontinence associated with obesity

Obesity has been shown to be significantly associated with SUI, independent of other risk factors (estrogen

*email: radadaniel@yahoo.com 
deficiency, a history of pelvic surgery, etc) [19]. Itis claimed that increased intra-abdominal pressure due to obesity negatively stresses the pelvic floor and contributes to the development of SUI, increased abdominal diameter and high body mass index have been associated with increased intra-abdominal pressure [20].

Richter et al have shown that intra-abdominal pressure at maximum cystometric capacity increased significantly $0.4 \mathrm{~cm} \mathrm{H}_{2} \mathrm{O}$ per unit of body mass index and $0.4 \mathrm{Cm} \mathrm{H}_{2} \mathrm{O}$ per $2 \mathrm{~cm}$ increase in abdominal circumference in obese women with incontinence [21]. Both rapid weight gain ( $\geq 20 \mathrm{~kg}$ over 4 years) and long periods with excess weight increase a woman's risk of developing urinary symptoms [18].

From another point of view, obesity has been shown to be a risk factor for peripheral nerve dysfunction, with impaired driving parameters in the median, peroneal, sural and tibial nerves, and the impact of obesity on neuronal function may be exacerbated by concomitant metabolic conditions [ 22].

Visceral fat level can be a predictor for SUI among women, as visceral adipose tissue is collected in the abdominal cavity and surrounds the internal organs; it is associated with a number of conditions, such as cardiovascular disease and insulin resistance. Excessive visceral adipose tissue is involved in inflammation of the bladder, possibly due to changes in neuroendocrine processes [23].

Townsend et al found that overweight women have a significantly higher risk of urinary leakage, the risk level increases by $3 \%$ for every $\mathrm{kg}$ gained, and the high body mass index increases the chances of developing SUl. Every $\mathrm{kg} / \mathrm{m}^{2}$ above normal grow th of body mass index increases the chances of SUI by 7\% [24]. Terauchi et al concluded that SUI is associated with high waist circumference, as well as a waist-to-hip ratio above normal limits among Japanese women [25].

\section{Management of stress urinary incontinence in obese women}

The management of this condition is important in terms of both SUI and obesity. The therapeutic options are multiple, from behavioral changes, pelvic floor muscle training, incontinence sessions, vaginal insertions, to retropubial suspensions of the bladder neck and bulking therapy.

Both surgical and non-surgical weight loss are associated with a significant improvement in SUI, most likely due to decreased intra-abdominal pressure.

Subak etal and Wing etal have shown that a body weight loss of 5\%-10\% can significantly improve SUI symptoms compared to other types of urinary incontinence [26,27].

The diabetes prevention program, following a randomized controlled trial, found that weight loss among women with prediabetes was more effective in controlling SUI (complication of diabetes) than metformin therapy, while another study concluded that weight loss reduced the chances of developing SUI by $40 \%$ among women with type 2 diabetes $[28,29]$.

Although intense physical activity may increase the frequency of SUI in obese women, moderate and continuous physical activity has been associated with a lower number of SUI episodes, moderate physical activity may help to strengthen the pelvic floor, which, in turn, may inhibit the frequency of episodes of SUI [24,30].

The lack of sleep contributes negatively to the SUI. An association between the lack of sleep, the accumulation of visceral fat and nocturia has been demonstrated among obese women with SUI [25,31]. From a dietary point of view, a high intake of saturated fats and carbonated drinks predisposes to an increased risk of SUI $[32,33]$. The views are controversial in terms of coffee consumption, with more studies being needed. Diets high in cholesterol, zinc and vitamin $B_{12}$ may favor the onset of SUI [33].

More studies are necessary in order to make evidencebased recommendations regarding cases of SUI in obese women. Physical activity remains an important part of weight control in obese women with concomitant SUI. Also, targeted behavioral therapy is an integrated part (selfmonitoring and goal setting).

A multidisciplinary approach is needed, which may include: an urologist, an urogynecologist, a gynecologist, a kinetotherapist, etc $[34,35]$.

Although weight loss is the main therapeutic approach, there are many impediments. Obese women are less likely to engage in physical activity, especially if they have SUI. Weight loss by bariatric surgery has multiple implications and contraindications.

From the point of view of drug treatment, Duloxetine was approved at European level. Duloxetine is effective in the treatment of SUI, but the associated risks, such as mental health problems and suicidality are very common, therefore it is not recommended as first-line therapy [36].

Laser therapy (minimally invasive therapy) in the treatment of mild and moderate SUI has led to a significant reduction in symptomatology [37]. Laser therapy acts by remodeling, that occurs due to a thermogenic effect on the collagen that forms the pelvic floor, this effect induces neoangiogenesis in the target tissues, neo-angiogenesis of collagen, increasing epithelial thickness, cellular glycogen content, providing greater support for the urethra [38,39].

The combined therapy is represented by: topical medical vaginal therapy and pelvic floor rehabilitation; vaginal estrogen administration can also act by reducing the frequency and amplitude of the detrusor contractions, by increasing the sensory threshold of the bladder and by promoting the relaxation of the detrusor muscle $[40,41]$. Local intravaginal therapy with estriol has been shown to be effective in treating postmenopausal SUI, urogenital atrophy, and recurrent lower urinary tract infections, especially when combined with exercises aimed at improving the muscle tone of the floor. However, the effects are not for long-term $[42,43]$.

Another option would be anti-incontinence surgery, that can be performed before weight loss begins, after weight loss or during weight loss [44-46]. SUI treatment should be individualized, with a careful assessment of symptoms and concomitant factors that may impede the use of surgery [47], and preoperative counseling should include discussions of potential benefits and harms of the procedure.

\section{Conclusions}

While the link between urinary incontinence and obesity is clear, the pathophysiology is not completely elucidated. Studies confirm that excess body weight is a significant risk factor for SUI. The main recommendation for obese women suffering from SUI is the weight loss, that will lead to the improvement of SUI symptoms and to an improved quality of life. Also, surgical weight loss in women with morbid obesity improves urinary incontinence. Finally, for those obese women who choose to undergo antiincontinence surgery, the overall results after surgery are good. 


\section{References}

1.*** Centers for Disease Control and Prevention. https://www.cdc.gov/ obesity/adult/defining.html. Accessed October 4, 2019.

2.OGDEN, C.L., CARROLL, M.D., FRYAR, C.D., FLEGAL, K.M., NCHS Data Brief, No. 219, November 2015. https://www.cdc.gov/nchs/data/ databriefs/db219.pdf. Accessed October 4, 2017.

3.DEE, A., KEARNS, K., O'NEILL, C., SHARP, L., STAINES, A., O'DWYER, V., FITZGERALD, S., PERRY, I.J., BMC Res Notes., 7, no. 1, 2014, p. 242.

4.ECKEL, R.H., ALBERTI, K.G., GRUNDY, S.M., ZIMMET, P.Z., LANCET., 375, no. 9710, 2010, p. 181-183.

5.FINUCANE, M.M., STEVENS, G.A., COWAN, M.J., DANAEI, G., LIN, J.K., PACIOREK, C.J ., SINGH, G.M., GUTIERREZ, H.R., LU, Y., BAHALIM, A.N., FARZADFAR, F., RILEY, L.M., EZZATI, M., Lancet., 377, no. 9765, 2011, p. 557-567.

6.POPESCU, D., ENE, R., POPESCU, A., CIRSTOIU, M., SINESCU, R., CIRSTOIU, C., Acta Endocrinologica (Buc)., 11, no. 1, 2015, p. 109-113. 7.SUBAK, L.L., RICHTER, H.E., HUNSKAAR, S., J Urol., 182, no. 6, 2009, p. S2-7.

8.GIOVANNUCCI, E., RIMM, E.B., CHUTE, C.G., KAWACHI, I., COLDITZ, G.A., STAMPFER, M.J., WILLETT, W.C., Am J Epidemiol., 140, no. 11, 1994, p. 989-1002.

9.VIGNOZZI, L., GACCI, M., CELLAI, I., SANTI, R., CORONA, G., MORELLI, A., RASTRELLI, G., COMEGLIO, P., SEBASTANELLI, A., MANESCHI, E., NESI, G., DE NUNZIO, C., TUBARO, A., MANNUCCI, E., CARINI, M., MAGGI, M., Prostate., 73, no. 8, 2013, p. 789-800.

10.TANG, K.-D., LIU, J., JOVANOVIC, L., AN, J., HILL, M.M., VELA, I., LEE, T.K-W., MA, S., NELSON, C., RUSSELL, P.J ., CLEMENTS, J.A. LING, M-T., Oncotarget, 7, no. 4, 2016, p. 4939-4948.

11.HE, B., CHEN, R., GAO, X., REN, S., YANG, B., HOU, J., WANG, L., YANG, O., ZHOU, T., ZHAO, L., XU, C., SUN, Y., Oncotarget., 7, no. 13, 2016, p. 17275-17285.

12.ORBAN, H., CIRSTOIU, C., ZAHARIA, C., CINCU, C., Rev. Chim. (Bucharest), 59, 2008, p. 688.

13.GARLEY, A.D., NABILA, N., Am J Obstet Gynecol, 124, no. 5, 2014, p. 1011-1027.

14.HOLROYD-LEDUC, J.M., STRAUS, S.E., JAMA, 291, no. 8, 2004, p. 986-995.

15.ROVNER, E.S., WEIN, A.J., Rev Urol, 6, no. 3, 2004, p. S29-S47.

16.TRIFANESCU, R.A., SOARE, D., CARSTOIU, C., POPESCU, G., PASCU, A.M., POROCH, V., TOMA, S., POIANA, C., Rev. Chim. (Bucharest), 69, no. 12,2018 , p. 3520-3523.

17.CORNU, J.N., MERLET, B., CUSSENOT, O., CANCEL-TASSIN, G., CIOFU, C., AMARENCO, G., HAAB, F., World J Urol., 29, no. 2, 2011, p. 239-242.

18.WESNES, S.L., Int Urogynecol J., 25, no. 6, 2014, p. 725-729.

19.MOMMSEN, S., FOLDSPANG, A., World J Urol., 12, no. 6, 1994, p. 319-322.

20.LAMBERT, D.M., MARCEAU, S., FORSE, R.A., Obes Surg., 15, no. 9 , 2005, p. 1225-1232.

21.RICHTER, H.E., CREASMAN, J.M., MYERS, D.L., WHEELER, T.L., BURGIO, K.L., SUBAK, L.L., Int Urogynecol J Pelvic Floor Dysfunct., 19, no. 12, 2008, p. 1653-1658.

22.HANEWINCKEL, R., IKRAM, M.A., FRANCO, O.H., HOFMAN, A., DRENTHEN, J., VAN DOORN, P.A., J Peripher Nerv Syst., 22, no. 2, 2017, p. 112-120.

23.DURSUN, M., OTUNCTEMUR, A., OZBEK, E., SAHIN, S., BESIROGLU, H., KOKLU, I., Int Urol Nephrol., 46, no. 12, 2014, p. 2297-2300.

24.TOW NSEND, M.K., DANFORTH, K.N., ROSNER, B., CURHAN, G.C., RESNICK, N.M., GRODSTEIN, F., Obstet Gynecol., 110, no. 2 ptl, 2007, p. 346-353.

25.TERAUCHI, T., HIROSE, A., AKIYOSHI, M., OWA, Y., KATO, K., KUBOTA, T., Menopause., 22, no. 10, 2015, p. 1084-1090.
26.SUBAK, L.L., WING, R., WEST, D.S., FRANKLIN, F., VITTINGHOFF, E., CREASMAN, J.M., RICHTER, H.E., MYERS, D., BURGIO, K.L., GORIN, A.A., MACER, J., KUSEK, J.W., GRADY, D., N Eng J Med., 360, no. 5, 2009, p. 481-490.

27.WING, R.R., CREASMAN, J.M., WEST, D.S., RICHTER, H.E., MYERS, D., BURGIO, K.L., FRANKLIN, F., GORIN, A.A., VITTINGHOFF, E., MACER, J., KUSEK, J.W., SUBAK, L.L., Obstet Gynecol., 116, no. 2 pt 1,2010, p. 284-292.

28.BROWN, J.S., WING, R., BARRETT-CONNOR, E., NYBERG, L.M., KUSEK, J.W., ORCHARD, T.J., MA, Y., Diabetes Care., 29, no. 2, 2006, p. 385-390.

29.PHELAN, P., KANAYA, A.M., SUBAK, L.L., HOGAN, P.E., ESPELAND, M.A., WING, R.R., BURGIO, K.L., DILILLO, V., GORIN, A.A., WEST, D.S., BROWN, J.S., J Urol., 187, no. 3, 2012, p. 939-944.

30.HANNESTAD, Y.S., RORTVEIT, G., DALTVEIT, A.K., HUNSKAAR, S., BJ OG., 110, no. 3, 2003, p. 247-254.

31.ILIESCU, L., MERCAN-STANCIU, A., TOMA, L., DODOT, M., ISCA, T., GRUMEZA, M. Proceedings of the $35^{\text {th }}$ Balkan Medical Week, Edited by Diaconu C. 2018, Filodiritto Editore, 138-143.

32.DALLOSSO, H.M., MCGROTHER, C.W., MATTHEWS, R.J., DONALDSON, M.M., BJU Int., 92, no. 1, 2003, p. 69-77.

33.DALLOSSO, H., MATTHEWS, R., MCGROTHER, C., DONALDSON. M., Eur J Clin Nutr., 58, no. 6, 2004, p. 920-926.

34.ILIESCU, L.E., MERCAN-STANCIU, A., TOMA, L., IOANITESCU, S. Antiphospholipid syndrome - a life threatening condition. Revista Romana de Medicina de Laborator, 27, no. 3, 2019, pp. 333-337.

35.BACALBASA, N., TARAS, C., ORBAN, C., ILIESCU, L., HURJUI, I., HURJUI, M., NICULESCU, N., CRISTEA, M., BALESCU, I. Atypical right hepatectomy for liver metastasis from ovarian leiomyosarcoma - a case report and literature review. Anticancer Research, 36, no. 4, 2016, pp. 1835-1840.

36.MAUND, E., SCHOW GUSKI, L., GOTZSCHE, P.C., CMAJ, 189, no. 5, 2017, p. E194-203.

37.FISTONIC, N., FISTONIC, I., GUSTEK, S.F., TURINA, I.S.,

MARTON, I., VIZINTIN, Z., KAŽIĖ, M., HRELJAC, I., PERHAVEC, T., LUKAÈ, M., Lasers Med. Sci., 31, no. 4, 2016, p. 635-643.

38.BARALDI, CE., PURICELLI, E., S. KULKES, S., G.L. MARTINS, G.L. JOLA, 59, 2001, p. 17-20.

39.MERTICARIU, M., JINGA, V., Arch Balk Med Union, 53, no. 3,

2018, p. 387-392.

40.MATSUBARA, S., OKADA, H., SHIRAKAWA, T., GOTOH, A., KUNO,

T., KAMIDONO, S., Urology, 59, no. 4, 2002, p. 621-625.

41.RADULESCU. A., MADAN, V., AUNGURENCI, A., BRATU, 0 .,

FARCAS, O., DINU, M., MISCHIANU, D. Romanian J ournal of Military Medicine, CXVIII, new series, no.3, 2015, p. 20-22.

42.CAPOBIANCO, G., DONOLO, E., BORGHERO, G., DESSOLE, F., CHERCHI, P.L., DESSOLE, S., Arch. Gynecol. Obstet., 285, no. 2, 2012, p. 397-403.

43.STANESCU, A.M.A., GRAJDEANU, I.V., SERBAN, B., BRATU, O.G., SOCEA, B., DIACONU, C. Arch Balk Med Union, 54, no. 2, 2019, pp. 339-344.

44.OSBORN, D.J ., STRAIN, M., GOMELSKY, A., ROTHSCHILD, J., DMOCHOWSKI, R., Urology., 82, no. 4, 2013, p. 759-763.

45.BODEAN, O., BRATU, O.G., MUNTEANU, O., MARCU, D., ARSENIESPINU, D., SOCEA, B., DIACONU, C., CIRSTOIU, M., Arch Balk Med Union, 53, no. 2, 2018, p. 281-284.

46.SOCEA, B., SMARANDA, A.C., NICA, A.A., BRATU, O.G., DIACONU, C., BALEANU, V.D., DAVITOIU, D.V., DIMITRIU, M., CARAP, A.C., BOBIC, S., CONSTANTIN, V.D. Postcolonoscopy acute appendicitis - our case series and review of literature. Arch Balk Med Union, 53, no. 4, 2018, pp. 599-602.

47.GHEORGHE, G., CEOBANU, G., ILIE, M., STANESCU, A.M.A., BRATU, O.G., DIACONU, C.C. Gastrointestinal and neurological manifestations in systemic lupus erythematosus. Arch Balk Med Union, 54, no. 3, 2019, pp. 555-560.

Manuscript received: 23.09 .2019 